\title{
A new species of Abacarus Keifer (Acari: Eriophyidae) from Brazil
}

\author{
Carlos Holger Wenzel Flechtmann' \& Aline Daniele Tassi ${ }^{2,3}$
}

1 Universidade de São Paulo (USP), Escola Superior de Agricultura “Luiz de Queiroz” (ESALQ), Departamento de Entomologia e Acarologia (LEA).
Piracicaba, SP, Brasil. ORCID: http://orcid.org/0000-0001-7745-8544. E-mail: chwflech@usp.br (senior professor)
2 Universidade de São Paulo (USP), Escola Superior de Agricultura “Luiz de Queiroz” (ESALQ), Departamento de Fitopatologia e Nematologia (LFN).
Piracicaba, SP, Brasil. ORCID: http://orcid.org/0000-0002-8622-5977. E-mail: alinetassi@gmail.com
3 Instituto Biológico, Laboratório de Biologia Molecular Aplicada. São Paulo, SP, Brasil.

\begin{abstract}
Zoysiagrass is an important ornamental and turfgrass cultivated in different countries. Recently, damage to this plant, characterized by a type of witch's broom and stunting were observed in southern Brazil, suggesting possible attack by mites. A detailed examination of these plants showed the presence of a new mite species, Abacarus zoysiae Flechtmann \& Tassi sp. nov., as responsible for the damage. The objective of this publication is to describe that new species, based on adult females and males.
\end{abstract}

Keywords. Abacarus zoysiae; Eriophyidae; Grass; Zoysia japonica.

\section{INTRODUCTION}

Abacarus is a mite genus described by Keifer (1944), containing the type species $A$. hystrix (Nalepa, 1896) and over 60 species are currently placed in this genus, both from monocotyledonous and dicotyledonous plants, about 36 species in monocotyledonous (Amrine \& Stasny, 1994, Amrine, pers. comm.). Abacarus hystrix has long been associated with a broad host range, an unusual characteristic for eriophyoid mites that have obligate interactions and long evolutionary relationships within their specific host plants (Oldfield, 1996).

Despite the direct damage to their hosts resulting in leaf discoloration or rusting, $A$. hystrix is known as the vector of rye grass mosaic virus and agropyron mosaic virus (Jeppson et al., 1975; Vacante, 2015). Due to this importance as a virus vector and the unusual host range, the identification of $A$. hystrix has been questioned and studied extensively, the reviews include mtDNA COI sequences analyses, morphometric analyses, and reproductive tests (Skoracka., 2002; Skoracka, 2008; Laska et al., 2018) which demonstrated the presence of cryptic diversity within the Abacarus genus and a pattern of host-associated differentiation within the complex (Skoracka, 2002; 2008; Skoracka et al., 2012, 2013, 2018; Miller et al., 2013; Navia et al., 2015; Cvrković et al., 2016; Laska et al., 2018, Duarte et al., 2019).
As many other eriophyid groups, Abacarus is known for the wax-like material produced over its body which has been mentioned as important for protection against water loss at times of low relative humidity (Vacante, 2015). The presence of wax-like material is also considered important for increasing total surface drag, which is relevant for wind dispersed mites of wide host-range, as A. hystrix (Vacante, 2015). In some parts of Europe, this is one of the most common and widely distributed eriophyid mites on grasses (Skoracka, 2004).

Zoysia japonica Steud., also known as zoysiagrass, is an ornamental commonly cultivated in southern Brazil and in different parts of the world. Recently, plants of this species with irregular elongation of culms were observed in São Paulo state, in southeastern Brazil. The objective of this publication is to describe a new Abacarus species found in association with zoysiagrass causing specific symptoms.

\section{MATERIAL AND METHODS}

Examination of symptomatic plants under a stereomicroscope showed the presence of dozens of eriophyoid mites. These were collected and mounted in modified Berlese Medium (Amrine \& Manson, 1996) on microscope slides. They were kept on a heating plate at circa $60^{\circ} \mathrm{C}$ for a week, for clarification and drying. The mounted mites 
were then examined using a phase-contrast microscope (Leitz Dialux 20), at 1,000 × magnification (plan-apochromatic lens) in immersion oil. Mites were identified to genus level according to Amrine et al. (2003). They were determined to constitute a new species, based on an examination of the world literature, as subsequently detailed, and hence they are here described.

Structures of taxonomic interest were measured using a graded eyepiece. Measurements are given in micrometers and unless otherwise specified correspond to the length of the structure. The terminology and description used for this mite follows mainly Amrine et al. (2003). For each female structure, the first number refers to the measurement of the holotype, which is followed (in parentheses) by the range of the paratype. For males, measurements of each structure refer to the range of the paratypes.

Dorsal annuli were counted from the first annulus behind the prodorsal shield rear margin; ventral semi-annuli, from the first annulus behind caudal end of genitalia. Line drawings were made with the aid of a lucid chamber.

Slides are deposited in the Mite Reference Collection of Escola Superior de Agricultura "Luiz de Queiroz",
Piracicaba, São Paulo, Brazil. Holotype position is marked on the slide.

For scanning electron microscopy (SEM) studies, additional mites were kept in $70 \%$ ethanol for $24 \mathrm{~h}$, and transferred to stubs with a double carbon tape, dried at room temperature, sputter coated with gold in a Baltec SDC 050, and examined on a JEOL JSM IT300. Photomicrographs were recorded digitally.

\section{RESULTS AND DISCUSSION}

\author{
Taxonomic analysis \\ Family Eriophyidae Nalepa, 1898 \\ Subfamily Phyllocoptinae Nalepa, 1892 \\ Tribe Anthocoptini Amrine \& Stasny, 1994 \\ Genus Abacarus Keifer, 1944 \\ Abacarus zoysiae sp. nov.
}

(Figs. 1-7)

Holotype: female, Brazil, São Paulo, Ribeirão Preto $\left(21^{\circ} 11^{\prime} 35.3^{\prime \prime} \mathrm{S}, 47^{\circ} 48^{\prime} 03.2^{\prime \prime} \mathrm{W}\right)$, col. Flávio Figueiredo, 25 Sep 2020.
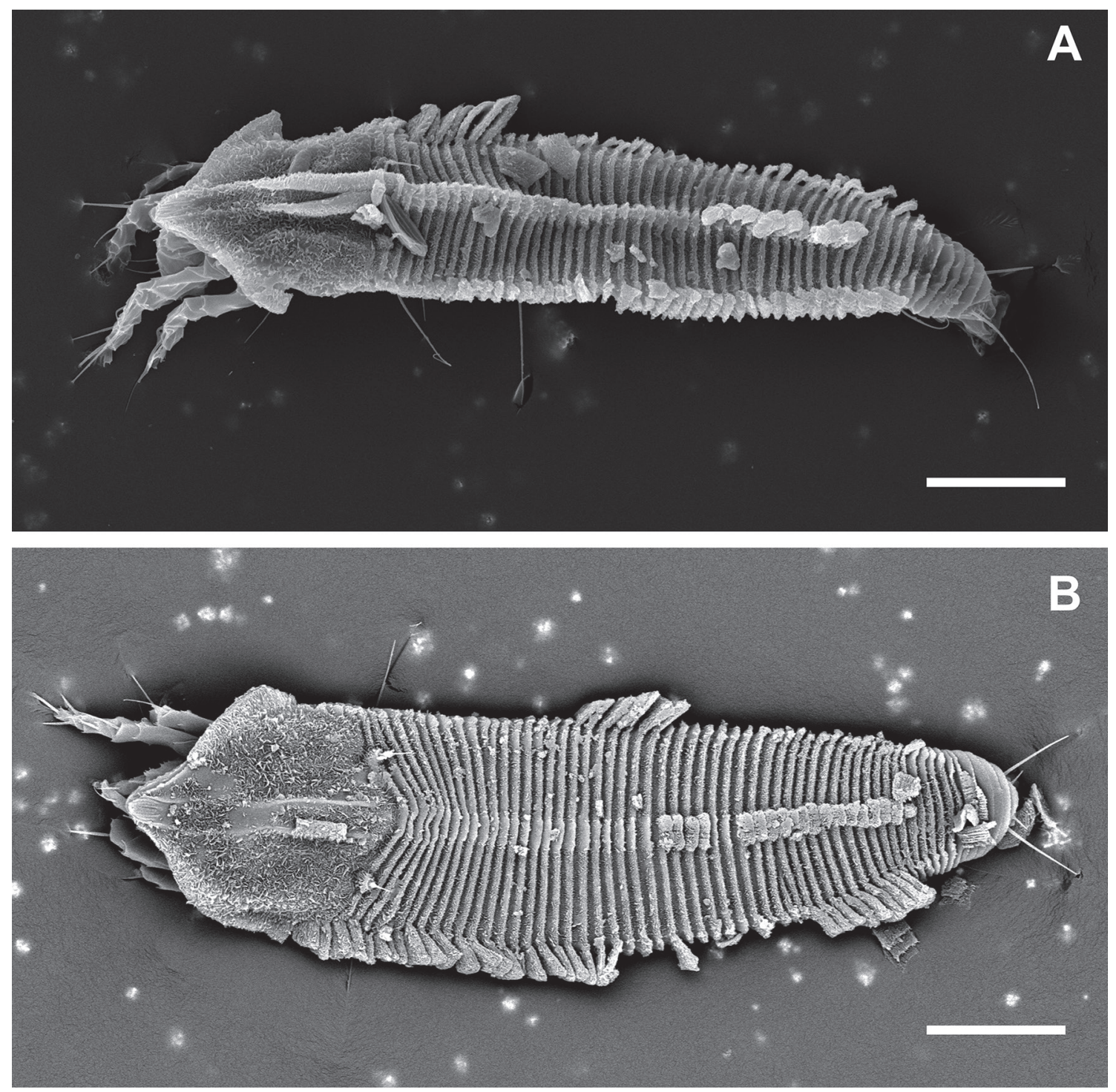

Figure 1. Abacarus zoysiae sp. nov. (A, B) Scanning electron micrographs (SEM) of dorsal view of specimens covered with wax-like secretion. Scale bar: $2 \mu \mathrm{m}$. 
Paratypes: 24 female, 10 males on 14 microscopic preparations, collected with holotype, same locality and collector as holotype.

\section{Diagnosis}

The new species is unique in presenting the prodorsal shield shaped as the profile of a five-sided diamond in dorsal view, with a prominent frontal lobe containing eight irregular longitudinal ridges. Shield ornamentation only represented by two admedian lines. With three coxigenital annuli and a short opisthosomal ventral seta II, e, 5-7 long.

\section{Description}

Female ( $\mathbf{N}=\mathbf{6})$ : Body elongate, 182 (171-202) length, 43 (41-50) wide, whitish, frequently covered with abundant white wax-like secretion (Figs. 1A, 1B and 7).

Gnathosoma: projecting obliquely downwards, basal pedipalp coxal seta (ep) 4 (3-4), apical dorsal pedipalp genual seta $(d), 5$ (5-6), chelicerae 18 (16-18).

Prodorsal shield: a five-sided diamond shaped in dorsal view, 40 (38-43) length, 39 (35-43) wide, prominent frontal lobe with 8 (8) longitudinal, irregular, scorings (Fig. 2). Shield ornamentation limited to two sub-median, parallel lines, with a slight median constriction, extending over entire shield length; otherwise smooth. With elongate anterolateral scorings. Scapular seta tubercles on shield rear margin, 22 (22-23) apart; scapular setae, (sc) 9
(9-10), projecting backwards, extending over 4 (4-5) dorsal opisthosomal annuli.

Coxisternal region: coxisternal plates and cervical plate with a few scattered elongate coarse dashes. Coxal seta I, 1b, 7 (6-8), 11 (9-11) apart; coxal seta II, 1a, 13 (11-13), 4 (5-6) apart; coxal seta III, 2a, 21 (21-27), 19 (19-22) apart; internal coxisternal apodeme (sternal line) 7 (7). Coxisternal annuli 3 (3), with fine, elongate, faint delicate microtubercles (Figs. 3B and 5B).

Opisthosoma: annuli about equal dorso-ventrally. Dorsal annuli with three longitudinal ridges: middorsal ridge ending about $13^{\text {th }}$ annulus from rear and extending in a short trough; lateral ridges ending at about $10^{\text {th }}$ annulus from rear. Caudal 9-10 dorsal annuli evenly arched. Dorsal annuli smooth, without microtubercles. Total dorsal annuli, 54 (54-60). Total ventral annuli, 52 (52-60), with narrow microtubercles, short in anterior annuli and becoming increasingly longer caudally. Lateral seta (c2) 40 (22-40), on annulus 3 (2-3) counting from genitalia rear margin. Ventral seta I (d) 36 (32-44), 27 (27-31) apart, on annulus 12 (12-14); ventral seta II (e) 6 (5-7), 12 (10-13) apart, on annulus 28 (28-35); ventral seta III (f) 24 (19-25), 19 (18-21) apart, on annulus 47 (47-56) or fifth from rear. Accessory seta (h1) 4 (4-5), caudal seta, h2, 40 (38-47). Genitalia 18 (18), 19 (19-10) wide, coverflap basally with two transverse lines of small beadlike granules and one line of larger, elongate, coarse granules; distal part with 10 (10) longitudinal ridges. Genital seta (3a) 14 (13-22) (Figs. 3A, 3B, 5A, and 5B).

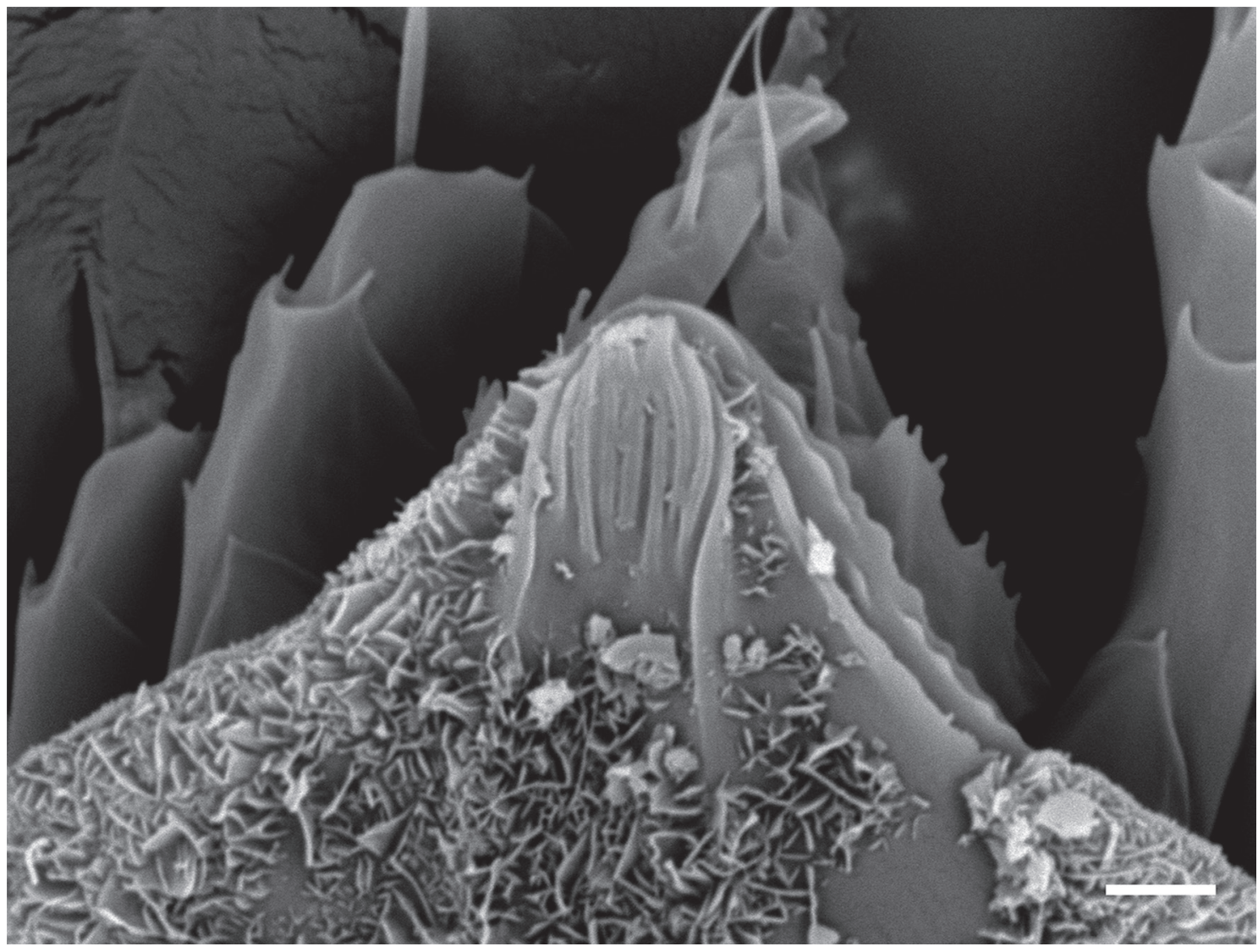

Figure 2. Abacarus zoysiae sp. nov. SEM of prodorsal shield, frontal lobe. Scale bar: $2 \mu \mathrm{m}$. 

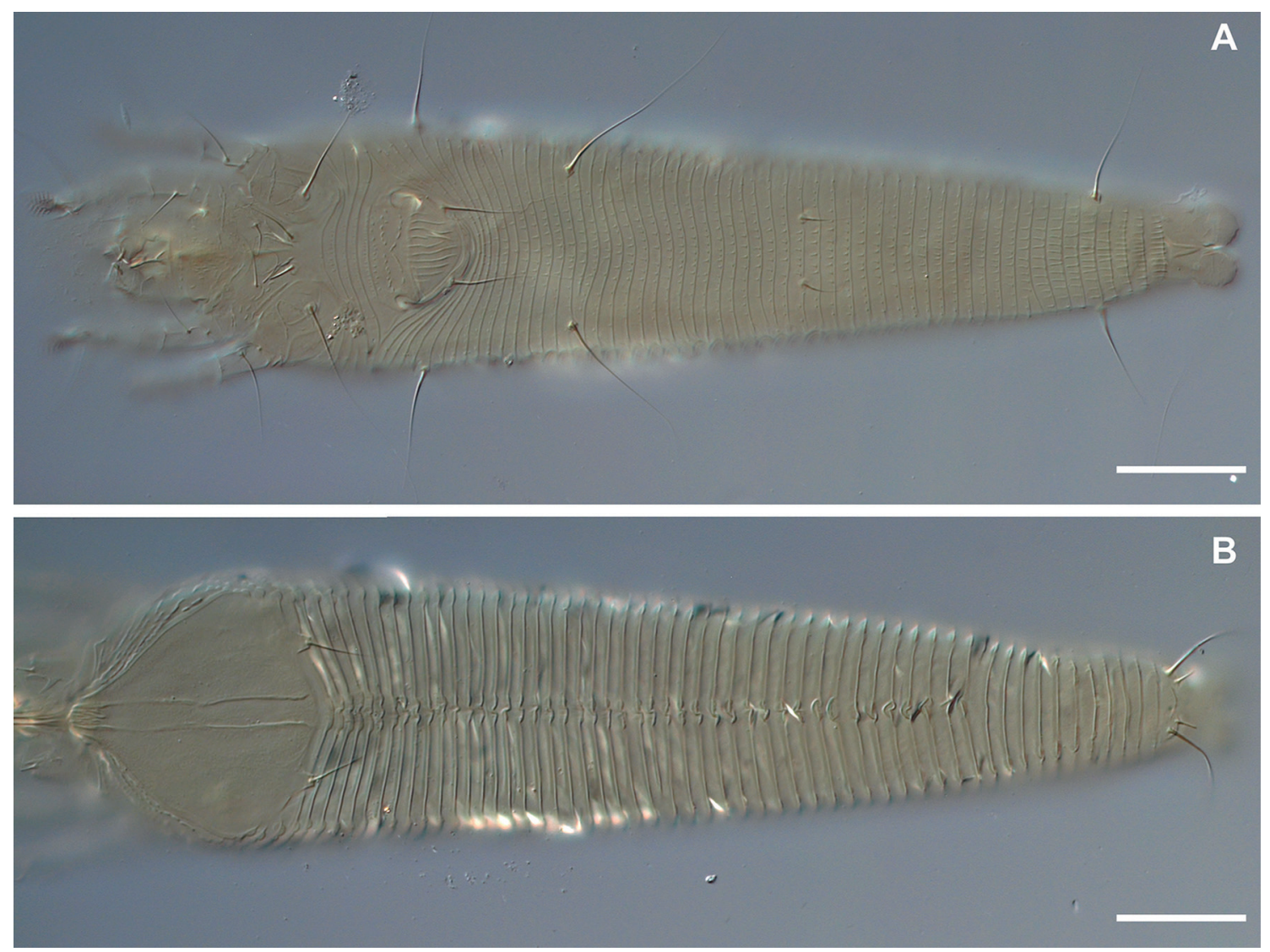

Figure 3. Abacarus zoysiae sp. nov. (A) ventral habitus of female; (B) Dorsal view of female. Scale bar: $20 \mu \mathrm{m}$.
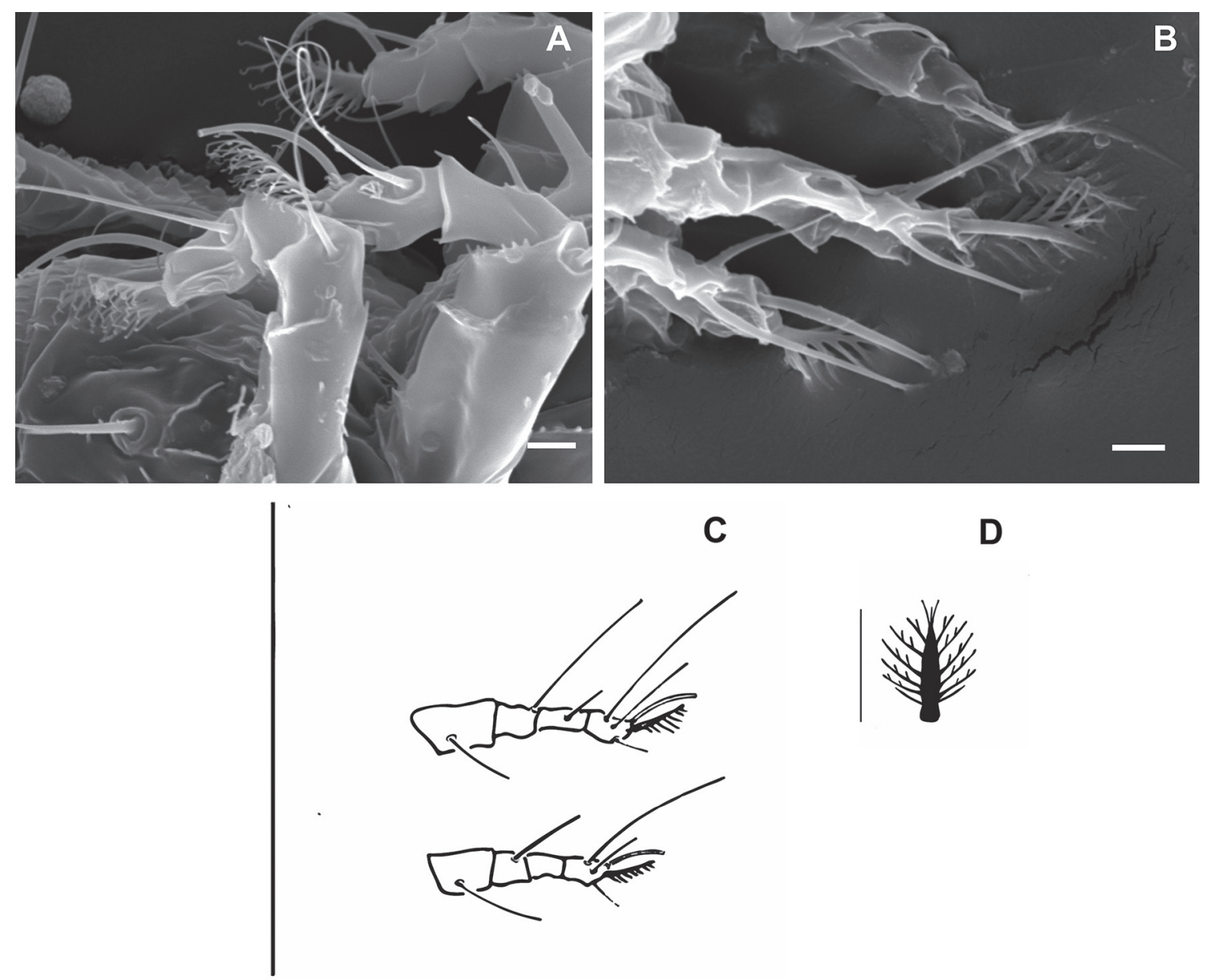

D

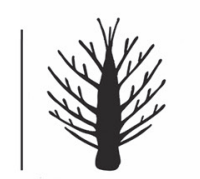

Figure 4. Abacarus zoysiae sp. nov. (A, B) SEM of legs I and II: (C) Drawing of legs I and II; (D) detail of empodium. Scale bar: A and B: $20 \mu \mathrm{m}$; C and D: $5 \mu \mathrm{m}$. 


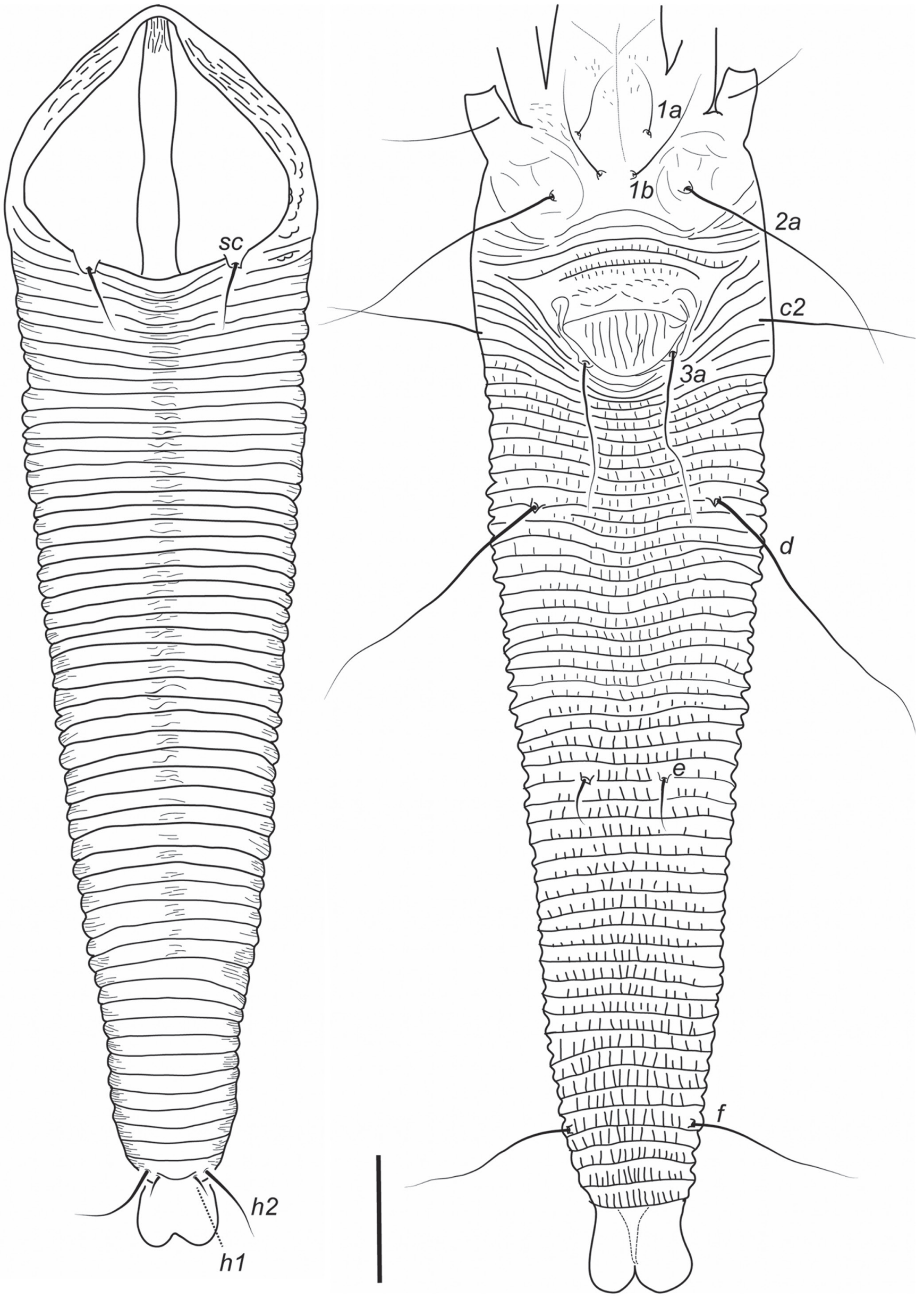

Figure 5. Abacarus zoysiae sp. nov. (A) Dorsal view of female; (B) Ventral view of female. Scale bar: $20 \mu \mathrm{m}$. 
Legs: leg I 27 (26-28); femur 10 (8-10), ventral basifemoral seta (bv) 9 (8-10); genu 5 (4-5), genual seta ( $\left.I^{\prime \prime}\right) 23$ (22-25); tíbia 6 (5-6), tibial seta (/) 6 (5-8), medio-distally; tarsos 5 (5-6), dorsal seta ( $\left.f t^{\prime}\right) 15$ (13-15), lateral seta $\left(f t^{\prime \prime}\right) 22$ (21-14), unguinal seta $\left(u^{\prime}\right) 5$ (4-5), solenidion $(\omega) 7$ (7-8), distally blunt, empodium simple 6 (6-7), 7-rayed. Leg II 25 (22-27); femur 7 (5-8), seta (bv) 14 (12-15); genu 4 (3-5), seta (I") 11 (9-12); tíbia 4 (3-4); tarsus $5(5-6)$, seta $\left(f t^{\prime}\right) 6(5-8)$, seta $\left(f t^{\prime \prime}\right) 22(21-23)$, seta $\left(u^{\prime}\right)$ 4 (4-5), solenidion $(\omega)$ blunt distally, 7 (7-8), empodium 6 (6-7), 7-rayed (Figs. 4A, 4B and 4C).

Male (n = 3): Similar to but smaller than female, 148-166 length; 34-40 wide (Figs. 6A and 6B).

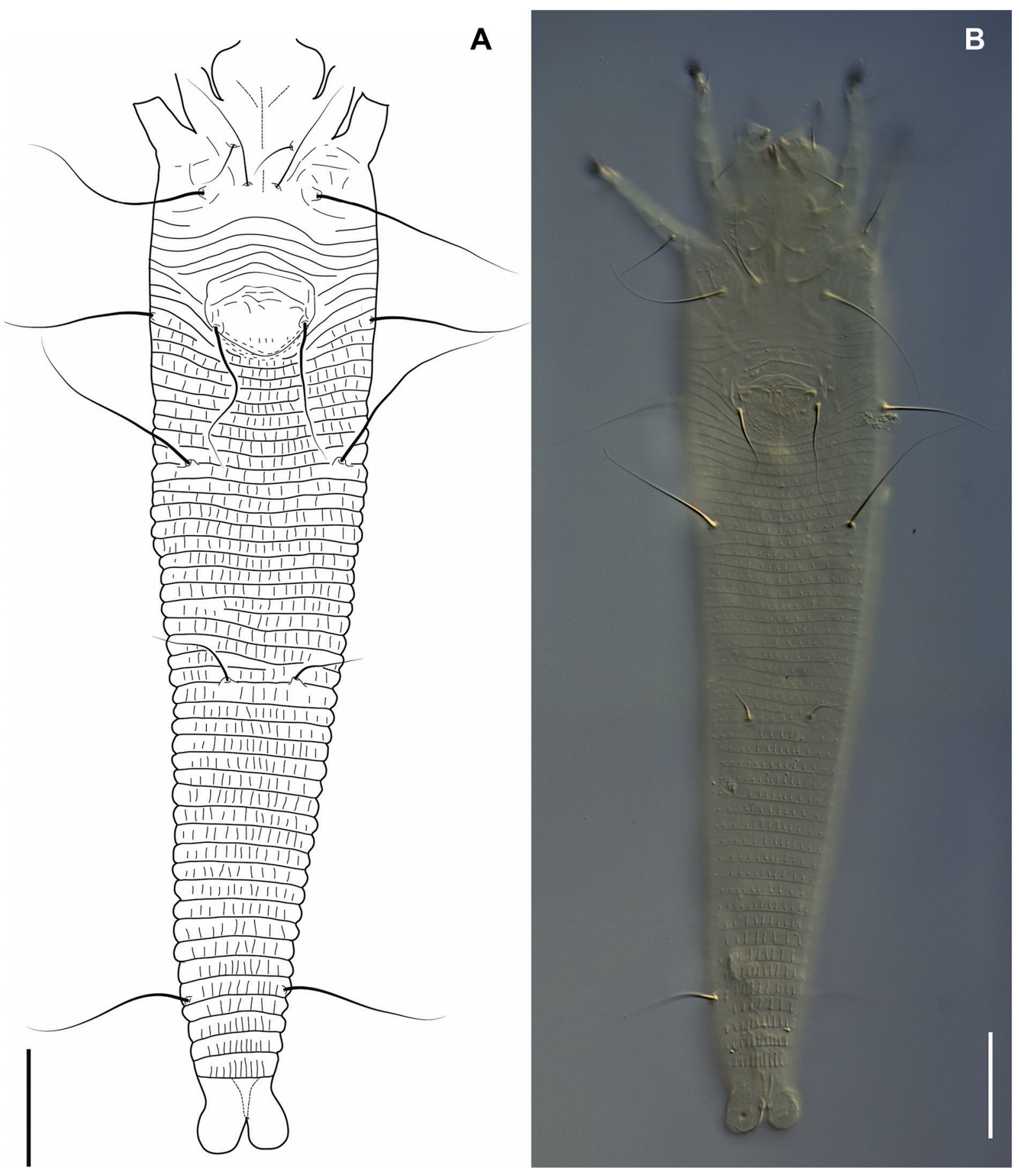

Figure 6. Abacarus zoysia sp. nov. (A) Drawing ventral view of male; (B) DIC ventral view of male. Scale bar: $20 \mu \mathrm{m}$. 


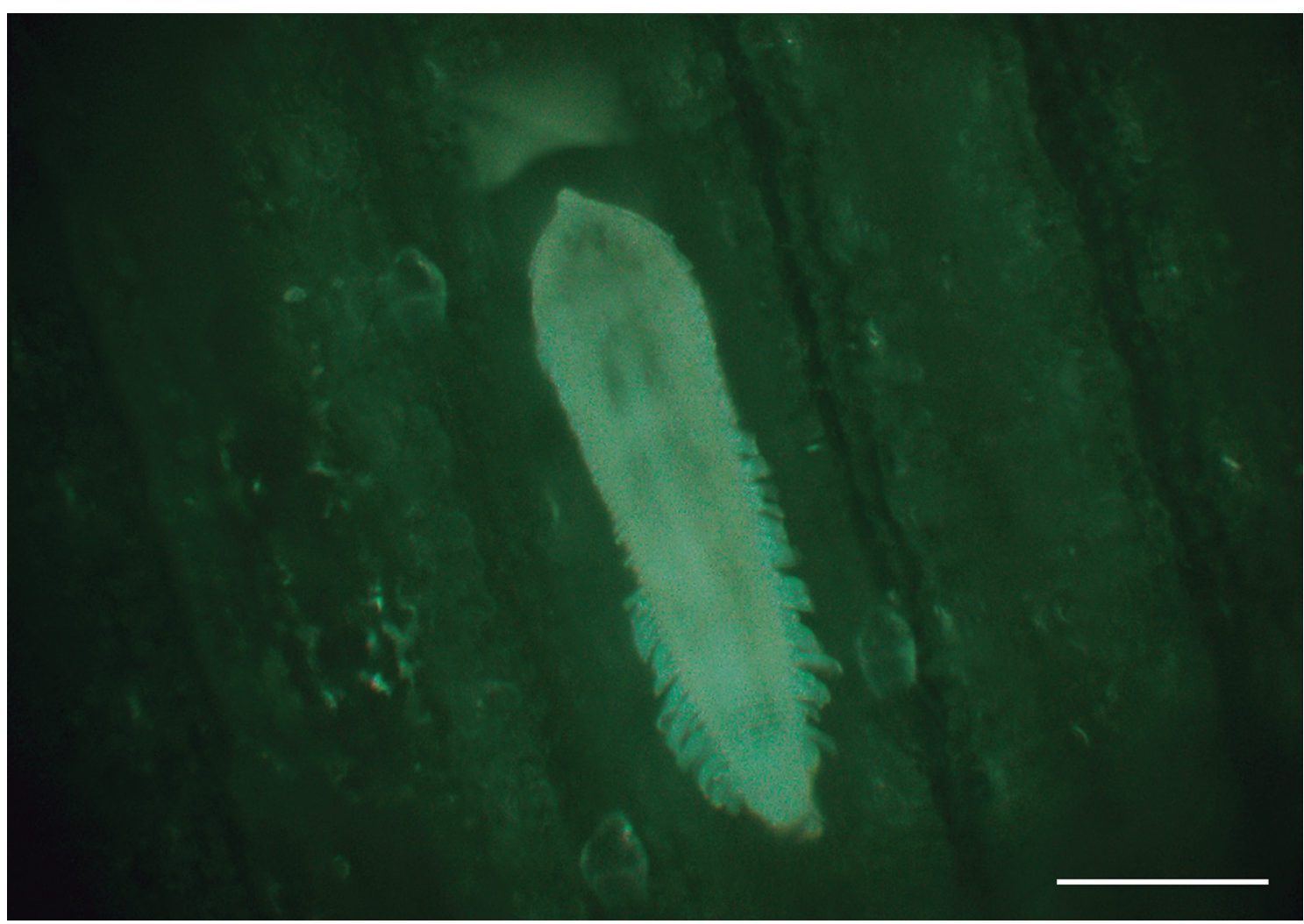

Figure 7. Abacarus zoysiae sp. nov. on Zoysia japonica. Scale bar: $50 \mu \mathrm{m}$.

Table 1. Relevant differences between the worldwide Abacarus species reported from grasses and with only two admedian lines on the prodorsal shield.

\begin{tabular}{|c|c|c|c|c|}
\hline Species & Prodorsal shield shape & $\begin{array}{c}\text { No. } \\
\text { coxigenital } \\
\text { annuli }\end{array}$ & $\begin{array}{c}\text { Opisthosomal } \\
\text { ventral seta II }(e) \\
\text { length }\end{array}$ & Epiginial cover \\
\hline A. acutatus Sukhareva, 1985 & 4 sided elongate diamond & $5-6$ & $30-40$ & $10-12$ ribs \\
\hline A. caucasicus Sukhareva, 1986 & 4 sided elongate diamond & 8 & $35-48$ & 12 ribs \\
\hline A. compactus Sukhareva, 1977 & Nearly hexagonal & $4-5$ & $25-40$ & 12 ribs \\
\hline A. delhiensis ChannaBasavanna, 1966 & Triangular & $7-8$ & 14 & 10 ribs \\
\hline A. doctus Navia \& Flechtmann, 2011 & Triangular & 7 & $13-16$ & $16-18$ ribs +2 basal transversal rows of microtubercles \\
\hline A. Ilolii Skoracka, 2009 & Triangular, elongate & 5 & $27-35$ & $12-14$ ribs +2 basal transversal rows of microtubercles \\
\hline A. longilobus Skoracka, 2002 & 4 sided elongate diamond & $5-7$ & $30-46$ & $10-12$ ribs \\
\hline A. neosacchari Duarte \& Navia, 2019 & Triangular & $6-8$ & $10-13$ & $12-15$ ribs $+2-3$ basal granulated lines \\
\hline A. phalaris Kuang, 1997 & 3 sided elongate Diamond & 5 & - & $10-12$ ribs \\
\hline A. sacchari Channabasavanna, 1966 & 5 sided, quadrangular with anterior narrowing & $7-8$ & 10 & $10-12$ ribs +2 basal transversal rows of microtubercles \\
\hline A. spodiopogoni Sukhareva, 1985 & 4 sided elongate diamond & $7-8$ & $40-47$ & $8-10$ ribs \\
\hline A. zoysiae Flechtmann \& Tassi sp. nov. & 5 sided diamond & 3 & $5-7$ & 10 ribs +1 basal transv. line of coarse granules and 2 lines of small granules \\
\hline
\end{tabular}

38-45 or $5^{\text {th }}$ from rear. Total dorsal annuli $45-51$, total ventral annuli 43-49. Seta $h 1$ 3-4; seta $h 2$ 32-35. Genitalia 11-13, 14-17 wide; genital seta, 3a, 15-20, reaching to basis of ventral seta $\mathrm{l}, \boldsymbol{d}$.

Legs: leg I 23-25; femur 7-8, bv 6-8; genu 4-5, I" 18-20; tíbia 4-5, l' 4-5; tarsus 5-6, ft' 11-14, ft" 18-22, u' 4-5, solenidion 5-7, empodium 6, simple, 7-rayed. Leg II 23-24; femur 6-8, bv 13-15; genu 4-5, I" 4-5; tíbia 3-4; tarsus 4-5, $\mathrm{ft}^{\prime}$ 7-8, ft" 20-21, u' 3-4, solenidion 7, empodium 6, simples, 7-rayed.

Type host plant: Zoysia japonica Steud., Poaceae, known as zoysiagrass and, in Brazil, "grama Esmeralda".
Relation to host: Causing damage of the type witch's broom and stunting, similar to what was reported for another eriophyid species, known as the bermudagrass stunt mite (Eriophyes zoysiae Baker, Kono \& O'Neill, 1986), in parts of the USA (Baker et al., 1986; Chong, 2013). Possible relation of a virus with this process cannot be disregarded, and should be later evaluated.

Etymology: The specific designation refers to Zoysia, the common and also genus name of the host plant.

Differential diagnosis: The new species is compared with all Abacarus species from grasses and in which ornamentation of the prodorsal shield is restricted to two admedian lines, being otherwise smooth (Table 1). 


\section{ACKNOWLEDGMENTS}

To M.E. Zanon (Itograss), for detecting the symptoms, collecting and sending us the samples that lead to the finding of the new species here described. To F.C.N. Esteca and N.C. Mesa for collecting and mounting part of the mites used for this study. To G.J. de Moraes, for the help in the preparation of this publication. To Dr. Elliot W. Kitajima for the access to the electron microscopy facilities (ESALQ-USP). This work was supported by the "Fundação de Amparo à Pesquisa do Estado de São Paulo" FAPESP proc: $2018 / 12252-8$, by fellowship to the author ADT.

\section{AUTHORS' CONTRIBUTIONS}

C.H.W.F. intercepted the specie, C.H.W.F. and A.D.T. concept the description, collected and interpreted the data. All authors discussed the results and contributed to the final manuscript.

\section{REFERENCES}

Amrine, J.W. \& Manson, D.C.M. 1996. Preparation, mounting and descriptive study of eriophyoid mites. In: Lindquist, E.E.; Sabelis, M.W. \& Bruin, J. (Eds.). Eriophyoid mites: their biology, natural enemies and control. Amsterdam, Elsevier. p. 383-396. (World Crop Pests, Vol. 6.

Amrine, J.W. \& Stasny, T.A. 1994. Catalog of the Eriophyoidea (Acarina: Prostigmata) of the world. Indira Publishing House. 798p.

Amrine, J.W.; Stasny, T.A. \& Flechtmann, C.H.W. 2003. Revised keys to world genera of Eriophyoidea (Acari: Prostigmata). Michigan, Indira Publishing House. 244p.

Baker, E.W.; Kono, T.\& O'Neill, N.R. 1986. Eriophyes zoysiae (Acari: Eriophyidae), a new species of eriophyid mite on zoysiagrass. International Journal of Acarology, 12(1): 3-6.

Channabasavanna, G.P. 1966. Contribution to the knowledge of Indian Eriophyid mites (Eriophyoidea: Trombidiformes: Acarina). Bangalore, University of Agricultural Sciences. 154p.

Chong, J.H. 2013. A witch's brew of troubles with the bermudagrass mite. Bermudagrass stunt mites are an increasing turfgrass problem at golf facilities with bermudagrass fairways and roughs. Green Section Record, 51(14): $4 p$.

Cvrković, T.; Chetverikov, P.; Vidović, B.; Petanović, R. 2016. Cryptic speciation within Phytoptus avellanae s.I. Eriophyoidea: Phytoptidae) revealed by molecular data and observations on molting Tegonotus-like nymphs. Experimental and Applied Acarology, 68(1): 83-96.

Duarte, M.E.; Mendonça, R.S.; Skoracka, A.; Silva, E.S. \& Navia, D. 2019. Integrative taxonomy of Abacarus mites (Eriophyidae) associated with hybrid sugarcane plants, including description of a new species. Experimental and Applied Acarology, 78(3): 373-401.

Jeppson, L.R.; Keifer, H.H. \& Baker, E.W. 1975. Mites injurious to economic plants. Berkeley, University of California Press. 614p. + 74 plates.

Keifer, H.H. 1944. Eriophyid studies XIV. The Bulletin of Department of Agriculture, 33: 18-38.

Kuang, H-Y. 1997. One new genus and four new species of Eriophyidae from China. Journal of Zhejiang Agricultural University, 23(3): 241-246.

Laska, A.; Majer, A.; Szydło, W.; Karpicka-Ignatowska, K.; Hornyák, M.; Labrzycka, A.; Skoracka, A. 2018 Cryptic diversity within grass- associated Abacarus species complex (Acariformes: Eriophyidae), with the description of a new species, Abacarus plumiger n. sp. Experimental and Applied Acarology, 76: 1-28.

Miller, A.D.; Skoracka, A.; Navia, D.; Mendonça, R.S.; Szydło W.; Schultz, M.B.; Smith, C.M.; Truol, G.; Hoffmann, A.A. 2013. Phylogenetic analyses reveal extensive cryptic speciation and host specialization in an economically important mite taxon. Molecular Phylogenetics and Evolution, 66(3): 928-940.

Nalepa, A. 1892. Neue Gallmilben. (4. Fort.) Anzeiger der kaiserlichen Akademie der Wissen-schaften. Mathematische-Naturwissenschaftliche Klasse, 29(13): 128.

Nalepa, A. 1896. Paraphytoptus, eine neue Phytoptiden Gat-tung. Anzeiger der kaiserlichen Akademie der Wissen-schaften. MathematischeNaturwissenschaftliche Klasse, 33(7): 55-56.

Navia, D.; Ferreira, C.B.; Reis, A.C.; Gondim-Jr., M.G. 2015. Traditional and geometric morphometrics supporting the diferentiation of two new Retracrus (Phytoptidae) species associated with heliconias. Experimental and Applied Acarology, 67: 87-12.

Navia, D.; Flechtmann, C.H.W.; Lindquist, E.E. \& Aguilar, H. 2011. A new species of Abacarus (Acari: Prostigmata: Eriophyidae) damaging sugarcane, Sacharrum [sic] officinarum L., from Costa Rica - the first eriophyoid mite described with a tibial seta on leg II. Zootaxa, 3025: 51-58.

Oldfield, G. 1996. Diversity and host plant specifcity. In: Lindquist, E.E.; Sabelis, M.W. \& Bruin, J. (Eds.). Eriophyoid mites-their biology, natural enemies and control. Amsterdam, Elsevier. p. 199-216. (World crop pests 6).

Skoracka, A. 2002. Two new species of eriophyoid mites (Acari: Eriophyoidea) from grasses in Poland. Zootaxa, 54: 1-15.

Skoracka, A. 2004. Eriophyoid mites from grasses in Poland (Acari: Eriophyoidea). Genus, (Suppl. 13): 203p.

Skoracka, A. 2008. Reproductive barriers between populations of the cereal rust mite Abacarus hystrix confirm their host specialization. Evolutionary Ecology, 22(5): 607-616.

Skoracka, A. 2009. Description of Abacarus Iolii n. sp. (Prostigmata: Eriophyoidea: Eriophyidae), a cryptic species within a grass-feeding Abacarus complex. International Journal of Acarology, 35(5): 405-417.

Skoracka, A.; Kuczyński, L.; Mendonça, R.S.; Dabert, M.; Szydło, W.; Knihinicki, D.; Truol, G.; Navia, D. 2012. Cryptic species within the wheat curl mite Aceria tosichella (Keifer) (Acari: Eriophyoidea), revealed by mitochondrial, nuclear and morphometric data. Invertebrate Systematics, 26(4): 417-433.

Skoracka, A.; Kuczyński, L.; Szydło, W.; Rector, B. 2013. The wheat curl mite Aceria tosichella (Acari: Eriophyoidea) is a complex of cryptic lineages with divergent host ranges: evidence from molecular and plant bioassay data. Biological Journal of the Linnean Society, 109(1): 165-180.

Skoracka, A.; Lopes, L.F.; Alves, M.J.; Miller, A.; Lewandowski, M.; Szydło, W.; Majer, A.; Różańska, E.; Kuczyński, L. 2018. Genetics of lineage diversification and the evolution of host usage in the economically important wheat curl mite, Aceria tosichella Keifer, 1969. BCM Evolutionary Biology, 18(122): 1-15.

Sukhareva, S.I. 1977. Two new species of Tetrapódili (Acarina) from the cereals. Entomologicheskoye Obozrenive, 61(3): 704-706 [Revue d'Entomologie de I'URSS].

Sukhareva, S.I. 1985. New species of mites (Acarina, Tetrapodili) living on gramineans in Primorskij Kraj [Maritime Territory]. Entomologicheskoye Obozreniye, 64(1): 227-234 [Revue d'Entomologie de I'URSS].

Sukhareva, S.I. 1986. New species of eriophyid mites (Acariformes: Tetrapodili) living on grasses in the USSR. Entomologicheskoye Obozrenive, 65(4): 850-855. [Revue d'Entomologie de l'URSS] (in Russian).

Vacante, V. 2015. The handbook of mites of economic plants. Identification, Bioecology and control. Boston, CABI. 890p. 